\title{
EHMTI-0041. ARTe Cluster project. Cluster headache - from pain to inspiration
}

\author{
P Rossi ${ }^{1 *}$, C Geraci $^{2}$, F Mesa Navarro ${ }^{2}$ \\ From 4th European Headache and Migraine Trust International Congress: EHMTIC 2014 \\ Copenhagen, Denmark. 18-21 September 2014
}

\section{Background and aim}

Barriers of communication play a crucial role in underestimating the disability induced by the headache disorders. Art is at its essence "a tool for creating empathy among human beings". ARTe Cluster is a project of Alleanza Cefalalgici Cluster aimed to collect artistic material to be used for promoting the activities of the association and to raise awareness about $\mathrm{CH}$ patients sufferings. In this study we analyzed the educational, artistic and therapeutic value of the paintings included in ARTe Cluster.

\section{Methods}

In 2011 we solicited $\mathrm{CH}$ patients' associations and figurative artists, throughout the world, to join to the ARTe Cluster project. Here we present a narrative analysis of artwork collected in the last two years.

\section{Results}

ARTe Cluster Project includes now 210 paintings ( 95 made by Cluster Headache sufferers; http://alcecluster. cefalea.it/). The exhibition expresses the full range of physical and psychological aspects related to $\mathrm{CH}$ with a prevalence of themes dealing with exhaustion, torture, isolation and fear.

\section{Conclusion}

$\mathrm{CH}$ represents a powerful source of inspiration for artistic expression. Art has proven to be able to create powerful icons of the disease that communicate about $\mathrm{CH}$ much more than single words can do and that may be used as educational tools to sensitize people and physicians about the dramatic sufferings of $\mathrm{CH}$ patients. An impressive number of $\mathrm{CH}$ patients demonstrated an artistic talent (12 of them were professional artists) possibly for the

${ }^{1}$ Headache Centre, INI, Grottaferrata (Rome), Italy

Full list of author information is available at the end of the article therapeutic aspect of the creative process of art making or for a natural artistic talent.

No conflict of interest.

\section{Authors' details}

${ }^{1}$ Headache Centre, INI, Grottaferrata (Rome), Italy. ${ }^{2}$ Europa, AlCe Cluster, Siegen, Germany.

Published: 18 September 2014

doi:10.1186/1129-2377-15-S1-C55

Cite this article as: Rossi et al:: EHMTI-0041. ARTe Cluster project. Cluster headache - from pain to inspiration. The Journal of Headache and Pain 2014 15(Suppl 1):C55.

\section{SpringerOpen ${ }^{\odot}$}

C 2014 Rossi et al; licensee Springer. This is an Open Access article distributed under the terms of the Creative Commons Attribution License (http://creativecommons.org/licenses/by/2.0), which permits unrestricted use, distribution, and reproduction in any medium, provided the original work is properly cited.
Submit your manuscript to a SpringerOpen ${ }^{\circ}$ journal and benefit from:

- Convenient online submission

- Rigorous peer review

- Immediate publication on acceptance

- Open access: articles freely available online

- High visibility within the field

- Retaining the copyright to your article

Submit your next manuscript at $>$ springeropen.com 